\title{
Advanced Oxidation Processes (AOPs) in Wastewater Treatment
}

\author{
Yang Deng ${ }^{1} \cdot$ Renzun Zhao $^{2}$
}

Published online: 18 September 2015

(C) Springer International Publishing AG 2015

\begin{abstract}
Advanced oxidation processes (AOPs) were first proposed in the 1980s for drinking water treatment and later were widely studied for treatment of different wastewaters. During the AOP treatment of wastewater, hydroxyl radicals $(\mathrm{OH} \cdot)$ or sulfate radicals $\left(\mathrm{SO}_{4}{ }^{-}\right)$are generated in sufficient quantity to remove refractory organic matters, traceable organic contaminants, or certain inorganic pollutants, or to increase wastewater biodegradability as a pre-treatment prior to an ensuing biological treatment. In this paper, we review the fundamental mechanisms of radical generation in different AOPs and select landfill leachate and biologically treated municipal wastewater as model wastewaters to discuss wastewater treatment with different AOPs. Generally, the treatment efficiencies rely heavily upon the selected AOP type, physical and chemical properties of target pollutants, and operating conditions. It would be noted that other mechanisms, besides hydroxyl radical or sulfate radical-based oxidation, may occur during the AOP treatment and contribute to the reduction of target pollutants. Particularly, we summarize recent advances in the AOP treatment of landfill leachate, as well as advanced oxidation of effluent organic matters (EfOM) in biologically treated secondary effluent (BTSE) for water reuse.
\end{abstract}

This article is part of the Topical Collection on Water Pollution

Yang Deng

dengy@mail.montclair.edu

Renzun Zhao

rzhoa3@lamar.edu

1 Department of Earth and Environmental Studies, Montclair State University, Montclair, NJ 07043, USA

2 Department of Civil and Environmental Engineering, Lamar University, Beaumont, TX 77710, USA
Keywords Hydroxyl radicals $\cdot$ Sulfate radicals $\cdot$ Chemical oxidation $\cdot$ Refractory organic pollutants $\cdot$ Landfill leachate . Effluent organic matter (EfOM) · Biologically treated secondary effluent (BTSE)

\section{Introduction}

Advanced oxidation processes (AOPs) utilizing powerful hydroxyl or sulfate radicals as a major oxidizing agent were first proposed in the 1980 s for potable water treatment. Later, AOPs were broadly applied for treatment of different types of wastewaters because the strong oxidants can readily degrade recalcitrant organic pollutants and remove certain inorganic pollutants in wastewater. The objective of this study was to review the fundamentals of and recent advances in the advanced oxidation processes for wastewater treatment. In particular, AOPs for treatment of landfill leachate are discussed in detail.

\section{Advanced Oxidation Processes}

Advanced oxidation processes (AOPs) were first proposed for potable water treatment in the 1980s [1,2], which are defined as the oxidation processes involving the generation of hydroxyl radicals $(\mathrm{OH} \cdot)$ in sufficient quantity to effect water purification. Later, the AOP concept has been extended to the oxidative processes with sulfate radicals $\left(\mathrm{SO}_{4}{ }^{-}\right)$. Different from common oxidants such as chlorine and ozone that have a dual role of decontamination and disinfection, AOPs are applied primarily for destruction of organic or inorganic contaminants in water and wastewater. Although AOP inactivation of pathogens and pathogenic indicators have been studied [3, 4], they are rarely employed for disinfection because these radicals 
have too short half-life (on the order of microseconds), so that the required detention times for disinfection are prohibitive due to extremely low radical concentrations [5]. When AOPs are applied for wastewater treatment, these radicals, as a powerful oxidizing agent, are expected to sufficiently destruct wastewater pollutants, and transform them to less and even non-toxic products, thereby providing an ultimate solution for wastewater treatment [6].

\section{Hydroxyl Radical-Based AOPs}

Hydroxyl radical is the most reactive oxidizing agent in water treatment, with an oxidation potential between $2.8 \mathrm{~V}(\mathrm{pH} 0)$ and $1.95 \mathrm{~V}$ (pH 14) vs. SCE (saturated calomel electrode, the most commonly used reference electrode) [5]. $\mathrm{OH} \cdot$ is very nonselective in its behavior and rapidly reacts with numerous species with the rate constants on the order of $10^{8}$ $10^{10} \mathrm{M}^{-1} \mathrm{~s}^{-1}$. Hydroxyl radicals attack organic pollutants through four basic pathways: radical addition, hydrogen abstraction, electron transfer, and radical combination [7]. Their reactions with organic compounds produce carbon-centered radicals ( $\mathrm{R} \cdot$ or $\mathrm{R} \cdot-\mathrm{OH})$. With $\mathrm{O}_{2}$, these carbon-center radicals may be transformed to organic peroxyl radicals (ROO·). All of the radicals further react accompanied with the formation of more reactive species such as $\mathrm{H}_{2} \mathrm{O}_{2}$ and super oxide $\left(\mathrm{O}_{2}{ }^{\circ}\right)$, leading to chemical degradation and even mineralization of these organic compounds. Because hydroxyl radicals have a very short lifetime, they are only in situ produced during application through different methods, including a combination of oxidizing agents (such as $\mathrm{H}_{2} \mathrm{O}_{2}$ and $\mathrm{O}_{3}$ ), irradiation (such as ultraviolet light or ultrasound), and catalysts (such as $\mathrm{Fe}^{2+}$ ) [6]. Hydroxyl radical generation mechanisms of the major AOPs for wastewater treatment are briefly summarized below.

\section{Ozone-Based AOPs}

Ozone $\left(\mathrm{O}_{3}\right)$ is a strong oxidant itself with an oxidation potential of $2.07 \mathrm{~V}$ vs. SCE. However, direct $\mathrm{O}_{3}$ oxidation is a selective reaction, with typical reaction rate constants of $1.0 \times 10^{0}-10^{3} \mathrm{M}^{-1} \mathrm{~s}^{-18}$, in which $\mathrm{O}_{3}$ preferentially reacts with the ionized and dissociated form of organic compounds, rather than the neutral form. Under certain conditions, $\mathrm{OH}^{-}$is produced from $\mathrm{O}_{3}$ to initiate the indiscriminate oxidation (indirect mechanisms). Different detailed mechanisms have been proposed to explain the complex $\mathrm{OH} \cdot$ generation, and the overall reaction involving $\mathrm{OH} \cdot$ generation is expressed as below [8].

$3 \mathrm{O}_{3}+\mathrm{H}_{2} \mathrm{O} \rightarrow 2 \mathrm{OH} \cdot+4 \mathrm{O}_{2}$

In the presence of other oxidants or irradiation, the $\mathrm{OH}$. yield can be significantly improved. For example, in the socalled peroxone $\left(\mathrm{O}_{3} / \mathrm{H}_{2} \mathrm{O}_{2}\right)$ system, the $\mathrm{O}_{3}$ decomposition and
$\mathrm{OH} \cdot$ production are enhanced by hydroperoxide $\left(\mathrm{HO}_{2}{ }^{-}\right)$produced from $\mathrm{H}_{2} \mathrm{O}_{2}$ decomposition.

$\mathrm{H}_{2} \mathrm{O}_{2} \rightarrow \mathrm{HO}_{2}{ }^{-}+\mathrm{H}^{+}$
$\mathrm{HO}_{2}{ }^{-}+\mathrm{O}_{3} \rightarrow \mathrm{OH} \cdot+\mathrm{O}_{2}^{-}+\mathrm{O}_{2}$

In the $\mathrm{O}_{3}$ /ultraviolet (UV) irradiation, $\mathrm{H}_{2} \mathrm{O}_{2}$ is generated as an additional oxidant primarily through $\mathrm{O}_{3}$ photolysis (Eq. 4)

$\mathrm{O}_{3}+\mathrm{H}_{2} \mathrm{O}+h v \rightarrow \mathrm{H}_{2} \mathrm{O}_{2}+\mathrm{O}_{2}$

As a consequence, $\mathrm{OH} \cdot$ can be generated, at a minimum, through three pathways: (1) ozonation (Eq. 1); (2) $\mathrm{O}_{3} / \mathrm{H}_{2} \mathrm{O}_{2}$ (Eqs. 2 and 3); and (3) photolysis of $\mathrm{H}_{2} \mathrm{O}_{2}$, as shown in Eq. 5.

$\mathrm{H}_{2} \mathrm{O}_{2}+h v \rightarrow 2 \mathrm{OH}$.

\section{UV-Based AOPs}

Hydroxyl radicals can be initiated by photons in the presence of catalysts or oxidants. The most common catalyst is titanium dioxide $\left(\mathrm{TiO}_{2}\right)$, a RO-type semiconductor. $\mathrm{TiO}_{2}$ particles are excited to produce positive holes in the valence band $\left(h v^{+}{ }_{\mathrm{vb}}\right)$ with an oxidative capacity, and negative electrons at the conduction band $\left(e_{\mathrm{cb}}^{-}\right)$with a reductive capacity, as follows:

$\mathrm{TiO}_{2}+h v \rightarrow e_{\mathrm{cb}}^{-}+h v^{+} \mathrm{vb}$

With the reactions of $\mathrm{OH}^{-}, \mathrm{H}_{2} \mathrm{O}$, and $\mathrm{O}_{2}{ }^{--}$at the surface of $\mathrm{TiO}_{2}$, these holes and electrons can further form hydroxyl radicals [9].

$h v^{+}{ }_{\mathrm{vb}}+\mathrm{OH}^{-}{ }_{\text {(surface) }} \rightarrow \mathrm{OH} \cdot$

$h v^{+}{ }_{\mathrm{vb}}+\mathrm{H}_{2} \mathrm{O}_{(\text {absorbed })} \rightarrow \mathrm{OH} \cdot+\mathrm{H}^{+}$

$e_{\mathrm{cb}}^{-}+\mathrm{O}_{2}$ (absorbed) $\rightarrow \mathrm{O}_{2}{ }^{--}$

In the presence of oxidants such as $\mathrm{H}_{2} \mathrm{O}_{2}$ or $\mathrm{O}_{3}$, additional $\mathrm{OH} \cdot$ may be yielded under the UV irradiation. For example, a $\mathrm{H}_{2} \mathrm{O}_{2}$ molecule is cleaved by UV irradiation to generate two $\mathrm{OH}$.

$\mathrm{H}_{2} \mathrm{O}_{2}+h v \rightarrow 2 \mathrm{OH} \cdot$

In addition, at a wavelength less than $242 \mathrm{~nm}, \mathrm{OH} \cdot$ can also be produced possibly through photolysis of $\mathrm{H}_{2} \mathrm{O}$.

$\mathrm{H}_{2} \mathrm{O}+h v \rightarrow \mathrm{OH} \cdot+\mathrm{H} \cdot$

\section{Fenton-Related AOPs}

Among these metals that are able to activate $\mathrm{H}_{2} \mathrm{O}_{2}$ and produce hydroxyl radicals in water, iron is the most frequently used. In the so-called Fenton process, $\mathrm{H}_{2} \mathrm{O}_{2}$ reacts with $\mathrm{Fe}^{2+}$ to generate strong reactive species. The reactive species 
produced are traditionally recognized as hydroxyl radicals, though other substances such as ferryl ions are proposed. The Fenton-related chemistry for water and wastewater treatment has been discussed in detail elsewhere [10]. The classical Fenton radical mechanisms primarily involve the following reactions:

$$
\begin{aligned}
& \mathrm{Fe}^{2+}+\mathrm{H}_{2} \mathrm{O}_{2} \rightarrow \mathrm{Fe}^{3+}+\mathrm{OH} \cdot+\mathrm{OH}^{-} \\
& \mathrm{Fe}^{3+}+\mathrm{H}_{2} \mathrm{O}_{2} \rightarrow \mathrm{Fe}^{2+}+\mathrm{HO}_{2}+\mathrm{H}^{+} \\
& \mathrm{OH} \cdot+\mathrm{H}_{2} \mathrm{O}_{2} \rightarrow \mathrm{HO}_{2}+\mathrm{H}_{2} \mathrm{O} \\
& \mathrm{OH} \cdot+\mathrm{Fe}^{2+} \rightarrow \mathrm{Fe}^{3+}+\mathrm{OH}^{-} \\
& \mathrm{Fe}^{3+}+\mathrm{HO}_{2} \rightarrow \mathrm{Fe}^{2+}+\mathrm{O}_{2} \mathrm{H}^{+} \\
& \mathrm{Fe}^{2+}+\mathrm{HO}_{2}+\mathrm{H}^{+} \rightarrow \mathrm{Fe}^{3+}+\mathrm{H}_{2} \mathrm{O}_{2} \\
& 2 \mathrm{HO}_{2} \rightarrow \mathrm{H}_{2} \mathrm{O}_{2}+\mathrm{O}_{2}
\end{aligned}
$$

$\mathrm{OH} \cdot$ is generated from Eq. 12 through electron transfer. However, $\mathrm{OH} \cdot$ produced can be scavenged by either of Fenton reagents as shown in Eqs. 13 and 14. Therefore, the optimal molar ratio of iron ion to hydrogen peroxide needs to be experimentally determined for minimization of the unwanted scavenging. Although Eq. 13 indicates that the produced $\mathrm{Fe}^{3+}$ from Eq. 12 can be reduced to $\mathrm{Fe}^{2+}$, the iron cannot be a catalyst in the Fenton system because the rate constant in Eq. 13 is several orders of magnitude less than that in Eq. 12. Consequently, $\mathrm{Fe}^{3+}$ forms iron sludge at typical water and wastewater treatment conditions. The sludge needs to be separately disposed of, thus increasing the treatment complexity and operational costs. Of note, the generation of hydroxyl radicals during the Fenton reaction is the most effective only at an acidic $\mathrm{pH}$ condition. As a result, the application of Fenton reaction for wastewater treatment is restricted in practice.

Based on the classical Fenton treatment scheme, three modified Fenton processes are proposed, including the Fenton-like system, photo-Fenton system, and electroFenton system. In the Fenton-like reaction, $\mathrm{Fe}^{2+}$ is replaced by ferric ion $\left(\mathrm{Fe}^{3+}\right)$, namely, the series of reactions in the Fenton system are initiated from Eq. 13 in the Fenton-like system, rather than from Eq. 12 in the traditional Fenton treatment. In the photo-Fenton reaction, UV irradiation is applied with the traditional Fenton system with a major purpose of enhancing the UV-induced reduction of dissolved $\mathrm{Fe}^{3+}$ to $\mathrm{Fe}^{2+}$. In the electro-Fenton reaction, either or both of the Fenton reagents may be generated through electrochemical methods.

\section{Other AOPs}

A few other AOPs have been studied for different wastewater treatment, such as ultrasound (US) irradiation and electronic- beam irradiation. Under the US irradiation $(16 \mathrm{kHz}-$ $100 \mathrm{MHz}$ ), alternate compression and rarefaction cycles of the sound waves can lead to three successive stages of cavities (i.e., nucleation, growth, and implosive collapse) that are made of vapor and gas-filled microbubble. The microbubble collapse can immediately generate a high temperature (4200 $5000 \mathrm{~K})$ and a high pressure (200-500 atm). Under such extreme conditions, water molecules in the form of gas within microbubbles are fragmented to generate hydroxyl radicals.

$\mathrm{H}_{2} \mathrm{O} \rightarrow \mathrm{OH} \cdot+\mathrm{H} \cdot$

Electronic-beam irradiation generates various free radicals in water through splitting water.

$$
\begin{aligned}
& \mathrm{H}_{2} \mathrm{O}+e^{-} \rightarrow 2.7 \mathrm{OH} \cdot+2.7 \mathrm{H}_{3} \mathrm{O}^{+}+2.6 e^{-}+0.7 \mathrm{H}_{2} \mathrm{O}_{2} \\
& +0.6 \mathrm{H} \cdot+0.45 \mathrm{H}_{2}
\end{aligned}
$$

The coefficients in Eq. 20 are the $G$ values that are defined as the number of excited states, radicals, or other products formed or lost in a system, when $100 \mathrm{eV}$ of energy is absorbed [6]. Besides $\mathrm{OH}$, the AOP generates also strong reducing species $-e^{-}$and $\mathrm{H}$.

\section{Sulfate Radical-Based AOPs}

$\mathrm{S}_{2} \mathrm{O}_{8}{ }^{2-}$ itself is a strong oxidant with a standard oxidation potential $\left(E^{\circ}\right)$ of $2.01 \mathrm{~V}[11,12]$. Once activated by heat, ultraviolet (UV) irradiation (Eq. 21), transitional metals (Eq. 22), or elevated $\mathrm{pH}, \mathrm{S}_{2} \mathrm{O}_{8}{ }^{2-}$ can form more powerful sulfate radicals $\left(\mathrm{SO}_{4}^{-{ }^{-}}, E^{\mathrm{O}}=2.6 \mathrm{~V}\right)$ to initiate sulfate radicalbased advanced oxidation processes [13, 14].

$$
\begin{aligned}
& \mathrm{S}_{2} \mathrm{O}_{8}^{2-} \stackrel{\Delta / \mathrm{UV}}{\rightarrow} 2 \mathrm{SO}_{4}^{--} \\
& \mathrm{S}_{2} \mathrm{O}_{8}^{2-}+\mathrm{M}^{n+} \rightarrow \mathrm{SO}_{4}^{--}+\mathrm{SO}_{4}^{2-}+\mathrm{M}^{n+1}
\end{aligned}
$$

Elevated $\mathrm{pH}$ can also activate persulfate, but the relevant mechanisms are still unclear [15]. In a thermally activated persulfate method, the temperature applied broadly ranges within 35 and $130{ }^{\circ} \mathrm{C}$ [15]. As seen in Eqs. 21 and 22, with the same molar persulfate concentration, the metal activation method only generates $50 \%$ of a sulfate radical yield produced from the heat or UV-activated persulfate method. Therefore, the metal activation method is not theoretically efficient. The most frequently used metals include ferrous (Fe(II)) and ferric (Fe(III)) ions, though other metals have been demonstrated to have an activation capability, such as $\mathrm{Cu}(\mathrm{I})$ and $\mathrm{Ag}(\mathrm{I})$ [16].

Similar to hydroxyl radicals, sulfate radicals are highly reactive species with a short lifespan, though both radical species have different reaction patterns. Hydroxyl radicals 
preferably add to $\mathrm{C}=\mathrm{C}$ bonds or abstract $\mathrm{H}$ from $\mathrm{C}-\mathrm{H}$ bonds during their reactions with organic compounds [17]. In contrast, sulfate radicals tend to remove electrons from organic molecules that are subsequently transformed to organic radical cations [18]. It would be noted that hydroxyl radicals can also be produced from sulfate radicals through Eqs. 23 and 24 [19].

$$
\begin{aligned}
& \mathrm{SO}_{4}^{--}+\mathrm{H}_{2} \mathrm{O} \rightarrow \mathrm{OH} \cdot+\mathrm{SO}_{4}^{2-}+\mathrm{H}^{+} \\
& \mathrm{SO}_{4}^{--}+\mathrm{OH}^{-} \rightarrow \mathrm{OH} \cdot+\mathrm{SO}_{4}^{2-}
\end{aligned}
$$

Particularly, Eq. 24 shows that more hydroxyl radicals can be generated from sulfate radicals at an alkaline condition.

\section{Multiple Mechanisms Occurring During AOPs for Wastewater Treatment}

Besides $\mathrm{OH} \cdot$ or $\mathrm{SO}_{4}{ }^{-}$-based oxidation, other mechanisms simultaneously occurring during the AOP treatment may remove target pollutants in wastewater. The contribution of the non-radical oxidative mechanisms in the contaminant removal may be dominant or insignificant, depending on the AOP type and reaction conditions. Mechanisms concurrently occurring in different AOP treatments are summarized in Table 1.

\section{AOPs for Treatment of a High-Strength Wastewater-Landfill Leachate}

Since the concept of AOPs was proposed in the 1980s, different advanced oxidation technologies have been widely studied and applied for treatment of municipal wastewater and various industrial wastewaters. The treatment efficiency relies heavily upon chemical properties of contaminants and operating conditions. It is impossible to cover all the investigations on the AOP treatment of wastewaters in this review. Rather, as an example, here, we review AOPs for treatment of a typical high-strength wastewater-landfill leachate.

Over the past five decades, landfilling has consistently remained the dominant disposal method of municipal solid wastes in the USA $[20,21]$. A major environmental concern of landfills is continuous production of landfill leachate. Leachate is formed when water passes through solid waste in a landfill cell and the water content of solid waste is above field capacity (FC) of the deposited waste. Landfill leachate is a high-strength wastewater, exhibiting acute and chronic toxicity, with a variety of organic wastes and inorganic species [22-26]. Dissolved organic matters, ammonia, heavy metals, and xenobiotic organic compounds are major contaminants in landfill leachate [22]. If not properly managed or treated, these contaminants may cause serious pollution to groundwater,
Table 1 Major mechanisms for organics removal during wastewater treatment by different

\begin{tabular}{|c|c|c|}
\hline AOP types & $\begin{array}{l}\text { Oxidant for } \\
\text { advanced oxidation }\end{array}$ & Other occurring mechanisms \\
\hline $\mathrm{O}_{3}$ & $\mathrm{OH}$ & Direct $\mathrm{O}_{3}$ oxidation \\
\hline $\mathrm{O}_{3} / \mathrm{H}_{2} \mathrm{O}_{2}$ & $\mathrm{OH} \cdot$ & $\begin{array}{l}\text { Direct } \mathrm{O}_{3} \text { oxidation } \\
\mathrm{H}_{2} \mathrm{O}_{2} \text { oxidation }\end{array}$ \\
\hline $\mathrm{O}_{3} / \mathrm{UV}$ & $\mathrm{OH} \cdot$ & UV photolysis \\
\hline $\mathrm{UV} / \mathrm{TiO}_{2}$ & $\mathrm{OH} \cdot$ & UV photolysis \\
\hline $\mathrm{UV} / \mathrm{H}_{2} \mathrm{O}_{2}$ & $\mathrm{OH} \cdot$ & $\begin{array}{l}\text { UV photolysis } \\
\mathrm{H}_{2} \mathrm{O}_{2} \text { oxidation }\end{array}$ \\
\hline Fenton reaction & $\mathrm{OH}$ & $\begin{array}{l}\text { Iron coagulation } \\
\text { Iron sludge-induced adsorption }\end{array}$ \\
\hline Photo-Fenton reaction & $\mathrm{OH}$ & $\begin{array}{l}\text { Iron coagulation } \\
\text { Iron sludge-induced adsorption } \\
\text { UV photolysis }\end{array}$ \\
\hline Ultrasonic irradiation & $\mathrm{OH}$ & $\begin{array}{l}\text { Acoustic cavitation generates transient high } \\
\text { temperatures }(\geq 5000 \mathrm{~K}) \text { and pressures }(\geq 1000 \mathrm{~atm}) \\
\text { and produce } \mathrm{H} \cdot \text { and } \mathrm{HO}_{2} \cdot \text {, besides } \mathrm{OH} \cdot\end{array}$ \\
\hline Heat/persulfate & $\mathrm{SO}_{4}^{-}$ & Persulfate oxidation \\
\hline $\mathrm{UV} /$ persulfate & $\mathrm{SO}_{4}^{-{ }^{-}}$ & $\begin{array}{l}\text { Persulfate oxidation } \\
\text { UV photolysis }\end{array}$ \\
\hline $\mathrm{Fe}(\mathrm{II}) /$ persulfate & $\mathrm{SO}_{4}^{--}$ & $\begin{array}{l}\text { Persulfate oxidation } \\
\text { Iron coagulation } \\
\text { Iron sludge-induced adsorption }\end{array}$ \\
\hline $\mathrm{OH}^{-} /$persulfate & $\mathrm{SO}_{4}^{-} / \mathrm{OH}$ & Persulfate oxidation \\
\hline
\end{tabular}
AOPs 
surface water, and soil [21]. For example, New Jersey is the US state with the most Superfund sites, and approximately $25 \%$ of these contaminated sites were polluted by landfill leachate [27]. Recently, leachate management has become an increasingly important component in integrated and sustainable solid waste management as a result of gradually tightened regulations and significant associated expenses. In the solid waste industry, leachate management has a typical capital cost ranging between $\$ 750 \mathrm{~K}$ and $\$ 14 \mathrm{M}$, accounting for $20-33 \%$ of operating costs in landfills (no. 1 single landfill operating expense) [28, 29].

The earliest leachate treatment began in the 1970s [30-32]. The initial efforts were focused on application of the biological and physical/chemical treatment technologies that have been widely used in treatment of municipal wastewater. However, limited success was accomplished because leachate contaminants are typically more complex and recalcitrant than sewage. In the 1990s, AOPs were first applied for treatment of landfill leachate, particularly mature or biologically stabilized leachate [33-36]. The primary purpose of AOP application includes the following: (1) to increase the biodegradability of organics for following biological treatment, (2) to directly remove organic constituents, or (3) to further degrade organics as a post-treatment unit for other technologies [37, 38].

\section{Treatment Efficiency}

Deng [37] summarized the treatment efficiencies of different AOPs for treatment of landfill leachate. Ozonation of landfill leachate removed $6-88 \%$ of chemical oxygen demand (COD) with an average value of $53 \%$ and a standard deviation of $24 \%$. The major operational parameters include $\mathrm{pH}$ and $\mathrm{O}_{3}$ dosage. As mentioned before, the oxidation mechanism shifts toward direct $\mathrm{O}_{3}$ oxidation under acidic conditions, whereas $\mathrm{OH} \cdot$ oxidation becomes dominant at an alkaline condition, particularly above $\mathrm{pH} 10.0 . \mathrm{O}_{3}$ preferentially attacks aromatics, olefins, phenols, and S-containing organics, but slowly reacts with acetylenes, aldehydes, ketones, alcohols, alkanes, and carboxylic acids [9], while $\mathrm{OH} \cdot$ almost reacts with most organic molecules, except organic compounds such as carbon tetrachloride, chloroform, tetrachloroethane, and trichloroethane in landfill leachate [39, 40]. Moreover, the COD removal efficiencies in the $\mathrm{O}_{3} / \mathrm{H}_{2} \mathrm{O}_{2}$ treatment of landfill leachate range from 18 to $78 \%$, with an average value of $43 \%$ and a standard deviation of $23 \%$. The COD removal efficiency in the $\mathrm{O}_{3} / U V$ treatment of landfill leachate varies between 31 and $83 \%$, with an average value of $52 \%$ and a standard deviation of $19 \%$. And, the $U V / H_{2} \mathrm{O}_{2}$ treatment of landfill leachate removed 57 and $92 \%$ of the initial COD, with an average value of $77 \%$ and a standard deviation of $11 \%$.

The Fenton processes, whether the traditional or modified, constantly exhibit a strong capacity for leachate treatment. Based on 24 data from 17 literatures, Deng
[37] reported that the COD removal efficiencies of Fenton treatment for landfill leachate range between 35 and $90 \%$, with an average COD removal efficiency of $71 \%$ and a standard deviation of $13 \%$. Singh and Tang [41] reviewed 30 publications on the Fenton treatment of landfill leachate and found that the COD removal varied between 31 and $95 \%$. Englehardt et al. [42] made preliminary cost analysis of different physical/chemical treatment technologies for landfill leachate and concluded that the Fenton process is the most cost-effective. However, solid iron sludge, as the iron reduction byproduct, is continuously produced accompanied with the mitigation of organic pollutants. The undesirable sludge needs to be disposed of, thereby increasing the operational treatment costs [43]. Moreover, the Fenton process is only effective at an acidic $\mathrm{pH}$ (typically 3.0-4.0) [43]. As a consequence, the $\mathrm{pH}$ adjustment significantly increases the treatment costs and risks in the storage, transportation, and handling of strong acid.

Besides solution $\mathrm{pH}$ and Fenton reagents' doses, the molar ratio of Fenton reagents (i.e., $\mathrm{Fe}(\mathrm{II})$ and $\mathrm{H}_{2} \mathrm{O}_{2}$ ) is an essential operating factor to determine the COD removal efficiency. Because either of the two chemicals can scavenge the $\mathrm{OH}$, the optimal molar ratio of $\mathrm{Fe}(\mathrm{II})$ to $\mathrm{H}_{2} \mathrm{O}_{2}$ should be experimentally determined to minimize their scavenging effects. Of note, both oxidation and iron sludge-induced coagulation during the Fenton treatment can reduce organics [44-48]. Their relative contributions to the COD removal rely heavily upon solution $\mathrm{pH}$, as well as the molar ratio and absolute doses of Fenton reagents [48].

\section{Treatment Issues}

Two critical issues have been proposed for hydroxyl radicalbased AOPs for treatment of landfill leachates [37]. Firstly, though a major purpose of AOP application is to increase leachate biodegradability for subsequent biological treatment reactors, the improvement in the leachate biodegradability is very poor in practices. The leachate effluent $\mathrm{BOD}_{5} / \mathrm{COD}$ after AOP treatment is below 0.50 in most cases [49]. Therefore, AOPs appear not to be a suitable pre-treatment option for biological treatment. Secondly, hydroxyl radical-based AOPs difficultly remove ammonia nitrogen, the other major leachate pollutant, because hydroxyl radicals have a very slow reaction rate with ammonia [50].

\section{Recent Studies}

Over the past 5 years, AOPs have remained a research focus as a leachate treatment option, and the knowledge of the AOP treatment of landfill leachate has been advanced. 
Sulfate Radical-Based AOPs for Leachate Treatment

Deng and Ezyske [51] first attempted to apply a heat-activated persulfate system for treatment of a mature landfill leachate. They found that the SR-AOP could simultaneously oxidize refractory organic matters and ammonia nitrogen, advantageous over traditional hydroxyl radical AOPs that was unable to remove ammonia nitrogen. In the thermally activated persulfate system, the treatment efficiency was primarily influenced by solution $\mathrm{pH}$, temperature, and persulfate dose. An acidic condition ( $\mathrm{pH} 3.0-4.0$ ), higher temperature, and higher chemical dose favored the treatment. Up to $100 \%$ ammonia and $91 \%$ COD could be finally removed by the sulfate radical AOPs. Later, different sulfate radical-based AOPs (SR-AOPs) have been studied. Zhang et al. [52] tested an electro/ $\mathrm{Fe}^{2+} /$ peroxydisulfate process and found that oxidation and coagulation both contributed to the COD reduction. The treatment was highly affected by $\mathrm{pH}$, current density, and chemical dose, and an optimal ferrous concentration existed for the treatment. Amr et al. [53, 54] optimized a combined ozonaton and persulfate oxidative system for treatment of a stabilized landfill leachate. The maximum removal values of COD, color, and $\mathrm{NH}_{3}-\mathrm{N}$ were 72,93 , and $55 \%$, respectively, and $\mathrm{BOD}_{5} / \mathrm{COD}$ was increased from 0.05 to 0.29 .

\section{AOPs for Mitigation of UV-Quenching Organic Matters in Landfill Leachate}

Discharge of leachate to publicly owned treatment works (POTWs) is a common and preferred leachate management practice in the USA, due to the lowest treatment cost and the least management complexity as compared to other strategies. However, the benefits of this option have diminished in many cases due to adverse impacts from the leachate discharged to POTWs, as it can significantly interfere with UV disinfection performance after the introduction of strongly UV-quenching substances in the leachate [55]. The emerging issue is seriously challenging the solid waste industry because a regulatory trend toward less chlorination disinfection by-products (DBPs), but with the same pathogen inactivation requirement, is forcing POTWs to turn from traditional chlorination to alternative UV disinfection. POTWs with UV disinfection that receive in excess of approximately $3 \%$ by volume of leachate are susceptible to ineffective disinfection and may reduce or eliminate leachate acceptance or require pre-treatment to remove UV-absorbing materials. Recent interests have been focused on AOPs for mitigation of the leachate-induced UV absorbance. For example, the Fenton process has been attempted as a polishing treatment for biologically treated leachate with a purpose of the UV-absorbing reduction. More than $90 \%$ of $\mathrm{UV}_{254}$ in raw leachate can be removed after the Fenton treatment. Particularly, Fenton oxidation targets bio- refractory UV-quenching humic substances that are mainly $>1 \mathrm{kDa}[56,57]$.

\section{Role of Inorganic Species in the AOP Treatment of Landfill Leachate}

Although hydroxyl radicals are the most powerful oxidants in engineering systems, hydroxyl radical AOPs typically achieve a moderate COD removal efficiency in treatment of a landfill leachate. Deng et al. [58] investigated the effects of inorganic species abundantly existing in landfill leachate on the Fenton treatment efficiency. Results showed that nitrate did not significantly affect the COD removal rate. In contrast, sulfate $\left(\mathrm{SO}_{4}{ }^{2-}\right)$ and chloride $\left(\mathrm{Cl}^{-}\right)$, particularly the latter, inhibited Fenton oxidation, because their competition with target organic pollutants for $\mathrm{OH} \cdot$ as well as their competition with $\mathrm{H}_{2} \mathrm{O}_{2}$ to form $\mathrm{Fe}$ (III) complexes prevented the $\mathrm{Fe}$ (II) regeneration from $\mathrm{Fe}(\mathrm{III})$ reduction.

\section{Fenton Treatment of Landfill Leachate}

Singh and Tang [41] recently completed statistical analysis of optimum Fenton oxidation conditions for landfill leachate. Based on this study, the optimal $\mathrm{pH}$ ranges at $2.5-4.5$ with a median $\mathrm{pH}$ of 3.0 for raw and coagulated landfill leachate and varies within $2.5-6.0$ with a median $\mathrm{pH}$ of 4.2 for biologically treated leachate. Moreover, a median optimum molar ratio of ferrous ion to hydrogen peroxide is 3.0, much lower than the theoretically calculated ratio. Furthermore, they found a universal Fenton oxidation relationship between COD removal efficiency $(\eta)$ and COD loading factor $\left(L_{\mathrm{COD}}\right)$, which is defined as the initial $\mathrm{COD}\left(\mathrm{COD}_{0}\right)$ of leachate with respect to available $\mathrm{O}_{2}$ for oxidation, for landfill leachate treatment [59], as follows:

$$
H=0.733 L_{\mathrm{COD}}-0.182 \quad\left(L_{\mathrm{COD}}=0.03-72.0\right)
$$

\section{AOPs for Treatment of Effluent Organic Matters in Biologically Treated Secondary Effluent}

Rapidly expanding population, escalating water consumption, and dwindling water resources have severely aggravated the water shortage problem on a global scale, particularly in arid and water-stressed areas, making water reuse a strategically important approach to meet the current and future water demand $[60,61]$. Water reclamation has been long practiced for non-potable urban, industrial, and agricultural scenarios, as well as to augment potable water supplies through indirect or direct reuse [60]. Among various reclaimed water sources, biologically treated secondary effluents (BTSE) produced from wastewater treatment plants (WWTPs) represent a stable 
non-seasonal source, generally meeting 87 of the 93 numerical primary and secondary drinking water standards without further treatment [62]. Effluent organic matters (EfOM) in BTSE, similar to other BTSE pollutants such as nutrients, play an essential role in tertiary wastewater treatment and water reuse. EfOM is a complex mixture primarily comprised of extracellular polymeric substances (EPS), soluble microbial products (SMPs), and natural organic matter (NOM) derived from drinking water sources [63, 64]. Detailed information regarding the EfOM characteristics is available elsewhere $[65,66]$. Despite a few benign effects in limited cases, EfOM has, at least, five adverse impacts on physical, chemical and biological treatment of BTSE [65], including the following:

1) Potential precursor for disinfection by-product formation

2) Fouling adsorbents and membranes

3) Increasing the dose of coagulant or oxidant

4) Causing corrosion

5) Supporting biomass growth as substrate in water distribution networks

Many US states have their own guidelines to limit the maximum organic content in reclaimed water (e.g., $\mathrm{BOD}_{5} \leq 10 \mathrm{mg}$ / $\mathrm{L}$ in urban unrestricted reclaimed water in New Jersey). Different treatment options are considered to remove EfOM in treated wastewater, among which AOPs have increasingly attained great attention.

AOPs have been well demonstrated to effectively reduce $\mathrm{UV}_{254}$ of EfOM (removal efficiency $>90 \%$ ) [65, 67]. However, the reported DOC removal varies broadly within a range of 15-70\% [67-72]. Here, reaction kinetics and thermodynamics information and reaction pathways on hydroxyl radical oxidation of EfOM are discussed. And, different AOP technologies for the removal of EfOM is described in detail elsewhere [66].

Electron pulse radiolysis techniques and ozonation tests are employed to determine absolute bimolecular reaction rate constants $\left(k_{\mathrm{OH}-\mathrm{EfOM}}\right)$ for the reactions between $\mathrm{OH} \cdot$ and EfOM (or certain EfOM isolates) [73-77]. The rate constants broadly range between 0.27 and $35.0 \times 10^{8} \mathrm{M}_{\mathrm{c}}^{-1} \mathrm{~s}^{-1}$ (Table 2). The disparity among the measured data is principally due to the different EfOM compositions. COD, retention onto $\mathrm{NH}_{2}$ extraction medium, TOC, and fluorescence index (FI) are recognized as major parameters, accounting for approximately $62 \%$ of the variability among the various $k_{\mathrm{OH}-\mathrm{EfOM}}$. The temperature dependence of the reactions between $\mathrm{OH} \cdot$ and EfOM allows for the determination of key Arrhenius activation energies $\left(E_{\mathrm{a}}\right)$ and thermodynamic parameters. A recent study indicates that $E_{\mathrm{a}}$ of three EfOM samples, which were calculated from kinetics tests at $8-41{ }^{\circ} \mathrm{C}$, were $15.16 \pm 1.32$, $10.71 \pm 2.02$, and $16.95 \pm 1.67 \mathrm{~kJ} \mathrm{~mol}^{-1}$, respectively [78].

EfOM plays a key role in advanced oxidation of BTSE because it as a major water matrix component is able to rapidly react with $\mathrm{OH}$, as aforementioned. The $\mathrm{OH} \cdot$ scavenging due to EfOM was greater than due to inorganic components such as ammonia and phosphorus. The relative reduction in the UV absorbance of EfOM during AOP treatment was strongly and unambiguously correlated with the removal of emerging micropollutants such as pharmaceutical and personal care products (PPCPs) [79]. Studies showed that these unselectively active radicals tend to attack more oxygen-rich, less hydrophobic, and more biodegradable EfOM molecules [80]. Meanwhile, $\mathrm{OH} \cdot$ can react with fluorophores and consistently reduce EfOM fluorescence. Fluorescence excitationemission matrix (EEM) analysis reveals that this fluorescence reduction is the most prominent in the EEM region associated with SMPs [71]. Of interest, a previous study compared ozonation and $\mathrm{UV} / \mathrm{H}_{2} \mathrm{O}_{2}$ (a commonly used AOP) for degradation of EfOM. Results showed that direct $\mathrm{O}_{3}$ oxidation and $\mathrm{OH}$. produced from $\mathrm{UV} / \mathrm{H}_{2} \mathrm{O}_{2}$ can both decompose biopolymers and effectively eliminate humics and other oxidation by-products. However, $\mathrm{O}_{3}$ poorly oxidizes low molar mass (LMM) acids that are accumulated throughout the treatment, while $\mathrm{OH} \cdot$ is capable to readily decompose the LMM acids,
Table 2 Absolute bimolecular reaction rate constants for the reaction between $\mathrm{OH} \cdot$ and $\mathrm{EfOM}$

\begin{tabular}{lll}
\hline$k_{\mathrm{OH}-\mathrm{EfOM}}\left(\times 10^{8} \mathrm{M}_{\mathrm{c}}^{-1} \mathrm{~s}^{-1}\right)$ & EfOM type & Ref. \\
\hline 2.5 & EfOM from 28 WWTPs & {$[76]$} \\
$0.27 \sim 1.21$ (average: $0.86 \pm 0.35)$ & EfOM from 8 WWTPs & {$[77]$} \\
$1.72 \pm 0.13$ & Hydrophobic neutral EfOM isolate from a WWTP & {$[75]$} \\
$3.62 \pm 0.31$ & Transphilic acid EfOM isolates from a WWTP & {$[75]$} \\
$4.53 \pm 0.53$ & Transphilic neutral EfOM isolates from a WWTP & {$[75]$} \\
$6.32 \sim 14.1$ & EfOM from 4 WWTPs & {$[74]$} \\
$14.3 \sim 35.0$ & $<1 \mathrm{kDa}$ EfOM from 4 WWTPs & {$[74]$} \\
$1.83 \pm 0.25$ & $<3 \mathrm{kDa}$ EfOM from 4 WWTPs & {$[74]$} \\
$1.32 \pm 0.23$ & $<5 \mathrm{kDa}$ EfOM from 4 WWTPs & {$[74]$} \\
$1.26 \pm 0.35$ & $<10 \mathrm{kDa}$ EfOM from 4 WWTPs & {$[74]$} \\
$2.3 \sim 2.8$ & EfOM from 2 WWTPs & {$[73]$} \\
\hline
\end{tabular}


suggesting that AOPs are advantageous over ozonation in terms of EfOM removal.

Identification of the oxidation products subsequent to advanced oxidation of EfOM is also of great interest. Fenton oxidation was tested to remove up to $30 \%$ of the total carbon concentration, accompanied with the formation of oxidation products such as oxalic, formic, and acetic acids and, less prominently, formaldehyde, acetaldehyde, propionaldehyde, and glycolaldehyde [79]. Production of these EfOM oxidation products is also correlated with EEM changes [71]. Another study examined the $\mathrm{OH} \cdot$ exposures and attendant changes of fluorescence-based parameters, which allowed for establishment of strong linear relationships between formation of the aldehydes and carboxylic acids and the relative changes of integrated fluorescence [81].

\section{Conclusions}

Traditional hydroxyl radical-based advanced oxidation processes have been studied for treatment of wastewaters over the past three decades. The major purpose of HR-AOP is to remove recalcitrant organic matters, traceable emerging contaminants, in addition to certain inorganic pollutants. The treatment efficiency relies primarily on the AOP types, physical/chemical properties of target pollutants, and operational conditions. Recently, SR-AOP has also attracted attention for wastewater treatment. Sulfate radicals have a similar strong oxidative capacity and a short lifespan but different reaction patterns from hydroxyl radicals. For example, SRAOPs are able to readily oxidize ammonia nitrogen in wastewater, which can be rarely removed by HR-AOPs. Particularly, AOPs for treatment of landfill leachate and EfOM in BTSE have been reviewed. Previous studies have demonstrated that AOPs are a technically viable option for leachate treatment and water reuse. In the future research, the development of cost-effective AOPs needs to be investigated.

\section{References}

1. Glaze WH. Drinking-water treatment with ozone. Environ Sci Technol. 1987;21(3):224-30.

2. Glaze WH, Kang J-W, Chapin DH. The chemistry of water treatment processes involving ozone, hydrogen peroxide and ultraviolet radiation. 1987.

3. Cho M, Chung H, Choi W, Yoon J. Different inactivation behaviors of MS-2 phage and Escherichia coli in $\mathrm{TiO} 2$ photocatalytic disinfection. Appl Environ Microbiol. 2005;71(1):270-5.

4. Ikai H, Nakamura K, Shirato M, Kanno T, Iwasawa A, Sasaki K, et al. Photolysis of hydrogen peroxide, an effective disinfection system via hydroxyl radical formation. Antimicrob Agents Chemother. 2010;54(12):5086-91.
5. Tchobanoglous G, Burton F, Stensel H. Wastewater engineering. New York: Metcalf \& Eddy Inc; 2003.

6. Huang C, Dong C, Tang Z. Advanced chemical oxidation: its present role and potential future in hazardous waste treatment. Waste Manag. 1993;13(5):361-77.

7. System SE. The UV/oxidation handbook. In 1994.

8. Gottschalk C, Libra JA, Saupe A. Ozonation of water and waste water: a practical guide to understanding ozone and its applications. John Wiley \& Sons; 2009.

9. Tang WZ. Physicochemical treatment of hazardous wastes. CRC Press; 2003.

10. Pignatello JJ, Oliveros E, MacKay A. Advanced oxidation processes for organic contaminant destruction based on the Fenton reaction and related chemistry. Crit Rev Environ Sci Technol. 2006;36(1):184.

11. Kolthoff IM, Stenger VA, Belcher R. Volumetric analysis. 2. Titration methods: acid-base, precipitation, and complexformation reactions. Interscience Publ; 1947.

12. Huling SG, Pivetz BE. In-situ chemical oxidation; DTIC Document. 2006.

13. House DA. Kinetics and mechanism of oxidations by peroxydisulfate. Chem Rev. 1962;62(3):185-203.

14. Kolthoff I, Miller I. The chemistry of persulfate. II. The reaction of persulfate with mercaptans solubilized in solutions of saturated fatty acid soaps1. J Am Chem Soc. 1951;73(11):5118-22.

15. Tsitonaki A, Petri B, Crimi M, Mosbæk H, Siegrist RL, Bjerg PL. In situ chemical oxidation of contaminated soil and groundwater using persulfate: a review. Crit Rev Environ Sci Technol. 2010;40(1):55-91.

16. Anipsitakis GP, Dionysiou DD. Radical generation by the interaction of transition metals with common oxidants. Environ Sci Technol. 2004;38(13):3705-12.

17. Neta P, Madhavan V, Zemel H, Fessenden RW. Rate constants and mechanism of reaction of sulfate radical anion with aromatic compounds. J Am Chem Soc. 1977;99(1):163-4.

18. Forsey SP. In situ chemical oxidation of creosote/coal tar residuals: experimental and numerical investigation. University of Waterloo; 2004.

19. Waldemer RH, Tratnyek PG, Johnson RL, Nurmi JT. Oxidation of chlorinated ethenes by heat-activated persulfate: kinetics and products. Environ Sci Technol. 2007;41(3):1010-5.

20. Tchobanoglous G, Kreith F. Handbook of solid waste management. New York: McGraw-Hill; 2002.

21. Ezyske C, Deng Y. Landfill management and remediation practices in New Jersey, United States. In Chapter. 2012.

22. Kjeldsen P, Barlaz MA, Rooker AP, Baun A, Ledin A, Christensen TH. Present and long-term composition of MSW landfill leachate: a review. Crit Rev Environ Sci Technol. 2002;32(4):297-336.

23. Calace N, Liberatori A, Petronio B, Pietroletti M. Characteristics of different molecular weight fractions of organic matter in landfill leachate and their role in soil sorption of heavy metals. Environ Pollut. 2001;113(3):331-9.

24. Calace N, Petronio BM. Characterization of high molecular weight organic compounds in landfill leachate: humic substances. J Environ Sci Health A. 1997;32(8):2229-44.

25. Christensen TH, Cossu R, Stegmann R. Landfilling of waste: leachate, vol. 1. CRC Press; 1992.

26. Huo S, Xi B, Yu H, He L, Fan S, Liu H. Characteristics of dissolved organic matter (DOM) in leachate with different landfill ages. J Environ Sci. 2008;20(4):492-8.

27. Ezyske CM, Deng Y. Landfill management and remediation practices in New Jersey, United States. INTECH Open Access Publisher; 2012. 
28. Walker T. Managing leachate at different landfills across the U.S.: perspectives from an owner. In EREF Regional Summit on Leachate Management, Philadelphia, PA. 2013.

29. Torrens, K., Leachate Management Decision Making \& Available Technologies. In EREF Regional Summit on Leachate Management, Philadelphia, PA. 2013.

30. Boyle W, Ham R. Biological treatability of landfill leachate. Journal (Water Pollution Control Federation). 1974;860-72.

31. Ho S, Boyle W, Ham R. Chemical treatment of leachates from sanitary landfills. J (Water Pollut Control Fed). 1974;1776-91.

32. Chian ES, DeWalle FB. Sanitary landfill leachates and their leachate treatment. J Environ Eng Div. 1976;102(2):411-31.

33. Kim S-M, Geissen S-U, Vogelpohl A. Landfill leachate treatment by a photoassisted Fenton reaction. Water Sci Technol. 1997;35(4): 239-48.

34. Steensen M. Chemical oxidation for the treatment of leachateprocess comparison and results from full-scale plants. Water Sci Technol. 1997;35(4):249-56.

35. Ince NH. Light-enhanced chemical oxidation for tertiary treatment of municipal landfill leachate. Water Environ Res. 1998;1161-9.

36. Deng Y. Physicochemical removal of organic contaminants in municipal landfill leachate. Landfill Res Focus. 2007;5-26.

37. Deng Y. Advanced oxidation processes (AOPs) for reduction of organic pollutants in landfill leachate: a review. Int J Environ Waste Manag. 2009;4(3):366-84.

38. Renou S, Givaudan J, Poulain S, Dirassouyan F, Moulin P. Landfill leachate treatment: review and opportunity. J Hazard Mater. 2008;150(3):468-93.

39. Bigda RJ. Consider Fenton's chemistry for wastewater treatment. Chem Eng Prog. 1995;91(12).

40. Jiménez L, Alzaga R, Bayona JM. Determination of organic contaminants in landfill leachates: a review. Int J Environ Anal Chem. 2002;82(7):415-30.

41. Singh SK, Tang WZ. Statistical analysis of optimum Fenton oxidation conditions for landfill leachate treatment. Waste Manag. 2013;33(1):81-8.

42. Englehardt JD, Deng Y, Meeroff D, Legrenzi Y, Mognol J, Polar J. Options for managing municipal landfill leachate: year 1 development of iron-mediated treatment processes. Final Rep Year. 2006;1: 0432024-06.

43. Deng Y, Englehardt JD. Treatment of landfill leachate by the Fenton process. Water Res. 2006;40(20):3683-94.

44. Yoon J, Cho S, Cho Y, Kim S. The characteristics of coagulation of Fenton reaction in the removal of landfill leachate organics. Water Sci Technol. 1998;38(2):209-14.

45. Lau IW, Wang P, Fang HH. Organic removal of anaerobically treated leachate by Fenton coagulation. J Environ Eng. 2001;127(7): 666-9.

46. Wang P, Lau IW, Fang HH, Zhou D. Landfill leachate treatment with combined UASB and Fenton coagulation. J Environ Sci Health A. 2000;35(10):1981-8.

47. Kang YW, Hwang K-Y. Effects of reaction conditions on the oxidation efficiency in the Fenton process. Water Res. 2000;34(10): 2786-90.

48. Deng Y. Physical and oxidative removal of organics during Fenton treatment of mature municipal landfill leachate. J Hazard Mater. 2007;146(1):334-40.

49. Bernardo-Bricker AR, Singh SK, Trovó AG, Tang WZ, Tachiev G. Biodegradability enhancement of mature landfill leachate using Fenton process under different COD loading factors. Environ Process. 2014;1(3):207-19.

50. Lin SH, Chang CC. Treatment of landfill leachate by combined electro-Fenton oxidation and sequencing batch reactor method. Water Res. 2000;34(17):4243-9.
51. Deng Y, Ezyske CM. Sulfate radical-advanced oxidation process (SR-AOP) for simultaneous removal of refractory organic contaminants and ammonia in landfill leachate. Water Res. 2011;45(18): 6189-94.

52. Zhang H, Wang Z, Liu C, Guo Y, Shan N, Meng C, et al. Removal of COD from landfill leachate by an electro/Fe 2+/peroxydisulfate process. Chem Eng J. 2014;250:76-82.

53. Amr SSA, Aziz HA, Adlan MN. Optimization of stabilized leachate treatment using ozone/persulfate in the advanced oxidation process. Waste Manag. 2013;33(6):1434-41.

54. Amr SSA, Aziz HA, Adlan MN, Bashir MJ. Pretreatment of stabilized leachate using ozone/persulfate oxidation process. Chem Eng J. 2013;221:492-9.

55. Zhao R, Gupta A, Novak JT, Goldsmith CD, Driskill N. Characterization and treatment of organic constituents in landfill leachates that influence the UV disinfection in the publicly owned treatment works (POTWs). J Hazard Mater. 2013;258:1-9.

56. Zhao R, Gupta A, Novak JT. Using Fenton's reagent as a polishing step for biologically treated landfill leachate. Proc Water Environ Fed. 2013;2013(19):386-408.

57. Gupta A, Zhao R, Novak JT, Douglas Goldsmith C. Application of Fenton's reagent as a polishing step for removal of UV quenching organic constituents in biologically treated landfill leachates. Chemosphere. 2014.

58. Deng Y, Rosario-Muniz E, Ma X. Effects of inorganic anions on Fenton oxidation of organic species in landfill leachate. Waste Manag Res. 2012;30(1):12-9.

59. Singh SK, Tang WZ, Tachiev G. Fenton treatment of landfill leachate under different COD loading factors. Waste Manag. 2013;33(10):2116-22.

60. USEPA. Guidelines for water reuse. 2012.

61. Watkinson A, Murby E, Costanzo S. Removal of antibiotics in conventional and advanced wastewater treatment: implications for environmental discharge and wastewater recycling. Water Res. 2007;41(18):4164-76.

62. Englehardt JD, Amy VP, Bloetscher F, Chin DA, Fleming LE, Gokgoz S, Rose JB, Solo-Gabriele H, Tchobanoglous G. Comparative assessment of human and ecological impacts from municipal wastewater disposal methods in Southeast Florida. Prepared for Florida Water Environment Association Utility Council. 2001.

63. Laspidou CS, Rittmann BE. A unified theory for extracellular polymeric substances, soluble microbial products, and active and inert biomass. Water Res. 2002;36(11):2711-20.

64. Liu H, Fang HH. Extraction of extracellular polymeric substances (EPS) of sludges. J Biotechnol. 2002;95(3):249-56.

65. Shon H, Vigneswaran S, Snyder S. Effluent organic matter (EfOM) in wastewater: constituents, effects, and treatment. Crit Rev Environ Sci Technol. 2006;36(4):327-74.

66. Michael-Kordatou I, Michael C, Duan X, He X, Dionysiou D, Mills $\mathrm{M}$, et al. Dissolved effluent organic matter: characteristics and potential implications in wastewater treatment and reuse applications. Water Res. 2015;77:213-48.

67. Goslan EH, Gurses F, Banks J, Parsons SA. An investigation into reservoir NOM reduction by UV photolysis and advanced oxidation processes. Chemosphere. 2006;65(7):1113-9.

68. Umar M, Roddick F, Fan L, Autin O, Jefferson B. Treatment of municipal wastewater reverse osmosis concentrate using UVCLED/H 2 O 2 with and without coagulation pre-treatment. Chem Eng J. 2015;260:649-56.

69. Alvarez P, Beltrán F, Masa F, Pocostales J. A comparison between catalytic ozonation and activated carbon adsorption/ozoneregeneration processes for wastewater treatment. Appl Catal B Environ. 2009;92(3):393-400. 
70. Michael I, Hapeshi E, Michael C, Varela A, Kyriakou S, Manaia C, et al. Solar photo-Fenton process on the abatement of antibiotics at a pilot scale: degradation kinetics, ecotoxicity and phytotoxicity assessment and removal of antibiotic resistant enterococci. Water Res. 2012;46(17):5621-34.

71. Li W, Nanaboina V, Zhou Q, Korshin GV. Changes of excitation/ emission matrixes of wastewater caused by Fenton-and Fenton-like treatment and their associations with the generation of hydroxyl radicals, oxidation of effluent organic matter and degradation of trace-level organic pollutants. J Hazard Mater. 2013;244:698-708.

72. Rodríguez-Chueca J, Polo-López M, Mosteo R, Ormad M, Fernández-Ibáñez P. Disinfection of real and simulated urban wastewater effluents using a mild solar photo-Fenton. Appl Catal B Environ. 2014;150:619-29.

73. Hoigné J, Bader H. Ozonation of water: "oxidation-competition values" of different types of waters used in Switzerland. Ozone Sci Eng. 1979;1(4):357-72.

74. Dong MM, Mezyk SP, Rosario-Ortiz FL. Reactivity of effluent organic matter (EfOM) with hydroxyl radical as a function of molecular weight. Environ Sci Technol. 2010;44(15):5714-20.

75. Westerhoff P, Mezyk SP, Cooper WJ, Minakata D. Electron pulse radiolysis determination of hydroxyl radical rate constants with Suwannee River fulvic acid and other dissolved organic matter isolates. Environ Sci Technol. 2007;41(13):4640-6.
76. Keen OS, McKay G, Mezyk SP, Linden KG, Rosario-Ortiz FL. Identifying the factors that influence the reactivity of effluent organic matter with hydroxyl radicals. Water Res. 2014;50:408-19.

77. Rosario-Ortiz FL, Mezyk SP, Doud DF, Snyder SA. Quantitative correlation of absolute hydroxyl radical rate constants with nonisolated effluent organic matter bulk properties in water. Environ Sci Technol. 2008;42(16):5924-30.

78. McKay G, Dong MM, Kleinman JL, Mezyk SP, RosarioOrtiz FL. Temperature dependence of the reaction between the hydroxyl radical and organic matter. Environ Sci Technol. 2011;45(16):6932-7.

79. Li W, Nanaboina V, Zhou Q, Korshin GV. Effects of Fenton treatment on the properties of effluent organic matter and their relationships with the degradation of pharmaceuticals and personal care products. Water Res. 2012;46(2):403-12.

80. Audenaert WT, Vandierendonck D, Van Hulle SW, Nopens I. Comparison of ozone and $\mathrm{HO}$ induced conversion of effluent organic matter (EfOM) using ozonation and UV/H 2 O 2 treatment. Water Res. 2013;47(7):2387-98.

81. Liu C, Tang X, Kim J, Korshin GV. Formation of aldehydes and carboxylic acids in ozonated surface water and wastewater: a clear relationship with fluorescence changes. Chemosphere. 2015;125: 182-90. 